\title{
GYPA Gene
}

National Cancer Institute

\section{Source}

National Cancer Institute. GYPA Gene. NCI Thesaurus. Code C38319.

This gene plays a role in erythrocyte regulation. 